\title{
FIELD TRIAL FOR TREATMENT OF DIARRHOEA IN CATTLE-CALVES IN SHARKIA GOVERNORATE
}

\author{
Emam, E. E., Shadia, A. R. and Saleh,M. A.
}

Animal Health Research Institute (Zagazig, Sharkia, Egypt)

\begin{abstract}
The present study was designed to investigate the cause of diarrhea among frezian calves,haematological and biochemical effects of diahrroea as well as evaluate the effect of gentamycin sulphate and sulphamix on treatment of diarrhea.58 frezian-calves aged from 10-30 days, weighting40-60 $\mathrm{kg}$ body weight belonged to a private farm at Sharkia Province were involved in this investigation for isolation and identification the causativ agent of diarrhea in newlly born calves. 28 Calves from the above calves were divided into four equal groups. .First group was clinically healthy calves free from internal and external parasite (control group),second group was calves suffering from diahrroea due to bacterial causes and treated by gentamycin sulphate and Rehydro-Zinc,third group was calves suffering from diahrroea due to cryptosporidia and treated by sulphamix and Rehydro-Zinc,fourth group was calves suffering from diahrroea due to mixed infection (bacterial and cryptosporidia causes)and treated by gentamycin sulphate and sulphamix Rehydro-Zinc.Faecal blood samples were collected from control and infected calves before and after treatment by 10,20 and30days post treatment for bacteriological, haematological and biochemical analysis.

Bacteriological and parasitological investigations of faecal swabs indicated that E. coli, proteus sp., klebsiella sp.and mixed infection (E.Coli and proteus sp-E.Coli and klebsiella sp.) in percentage of $20.69 \%, 13.79 \%, 10.34 \%, 6.90 \%$ and $12.07 \%$ respectively, Moreover cryptosporidium sp.was found in (36.20\%)in diarrhoeic calves, either alone $(13.79 \%)$ or mixed with bacteria( E.coli and Cryptospordium sp. 6.90\% Proteus sp and Cryptospordium sp.10.34\% Klebsiella sp . and Cryptospordium sp. $5.17 \%$ ).
\end{abstract}


Antibiogram studies reveald that the activity of gentamycin and other antibiotic disc in vitro against previous isolated bacteria from diarrhoeic calves either alone or mixed infection by disc diffusion test,showed that the gentamycin was the highest effective than other tested drugs.

Haemogram picture of diarrhoeic calves due to bacteria or crytosporidia induce significant increase in erythrocytic count,haemoglobin content,packed cell volume percent, Meanwhile leukogram picture of diarrhoeic calves due to bacteria revealed revealed significant increase in total leukocytic count, eosinophils and significant decrease in monocytes coupled with insignificant increase in neutrophils,lymphocyte and basophil. but diarrhoeic calves due to crytosporidia and mixed infection induce a significant increase in total leukocytes count and lymphocytes but induce insignificant increase in neutrophils and insignificant decrease in monocytes, eosinophils and basophil.

The present work revealed that,diarrhoeic calves showed a significant elevation in the transaminases enzymes (AST-ALT) alkaline phosphatase, urea,creatinine and potassium but significant decrease in glucose, total protein, albumin, globulin, inorganic phosphorus ,magneisum and sodium but albumin /globulin ratio in signifi-cantly decreased were observed in diarrhoeic calve due to bacterial, crytosporidia and mixed infection but change of biochemical parameter due to mixed infection is more severe.

Excellent improvement in clinical symptoms,blood picture and blood serum constituents were observed following treatment with gentamycin with Rehy-dro zinc and sulphamix with Rehydro-Zinc either alone or in combination .

bacterial, crytosporidial and mixed infection induce some adverse effect on blood picture and biochemical parameters but mixed infection induce severe changes. The adverse effect on blood picture and biochemical parameters were returned to the normal levels at 30 days post treatment by gentamycin and sulphamix either alone or together. 


\section{INTRODUCTION}

One of the major problems in calve breading is the control of infectious diseases specially enteritis.During recent years interest was directed to study diarrhea in calves. During the first few months of life,diseases that affected young domestic animals cause great losses of animal industry, that is because the immune system of animals at young age is not well developed and the maternal immunity would not withstand variable infections (Pugh 2002). Diarrhoea is very common in neonatal calves in a breeding or dairy herd have a negative influence on reaching basic production goals due to calves death, treatment costs and time spent on care as well as subsquent chronic illthrift and poor growth Bazeley (2003). The disease known as Syndrome of Neonatal diarrhoea or white scours is seen in general in calves less than 10 days old and until 45 days of age Cullor (1985).

Diarrhoea is a symptom caused by various agents as bacterial, viral, protozoal, mixed infection and environmental factors (Smith and Sherman 1994). Diarrhoea in calves is caused by a variety of aetiological agents including Escherichia coli Abd-Ellha (2004) Amongest the causes infections are the most important.The most frequent of these are Escherichia coli, Clostridium sp.Corona virus, Rotavirus and Protozoa Bellinzoni (1990). Mixed infections are frequently seen and clinical signs are usually more severe where more than pathogen is involved Bazeley (2003).

Cryptosporidium species is now recognized as a primary enteric pathogen in animals Janoff and Reller(1987). The parasite is in the phylum Apicomplexa and part of the group of parasites commonly referred to as coccidia Fayer, et. al.(1997). In cattle, clinical disease and Kafr El-Sheikh Vet. Med. J. Vol. 4 No. 1 (2006) 
shedding of the parasite is usually limited to calves under a few months of age (Anderson and Hall 1982). cryptosporidium will be associated with other bacterial or viral pathogens that occur in calves at the same age as Cryptosporidium. Generally, these infections will affect calves more severely than in cases of Cryptosporidiosis alone (Kirkpatrick, 1985).

Gentamycin is an aminoglycoside isolated from micromonospora purpurea .It is a broad spectrum bactericidal activity (Tobin,1979). the mechanism of action of gentamycin involves irreversible inhibition of bacterial ribosomes and therefore impaired protein synthesis (Bryan and Kwan,1983). Use of this aminoglycoside in veterinary and human medicine has been wide spread because of its efficacy in treating drug resistant gram-negative bacteria infections (Karlowsky, et.al. 1995). Unfortunately, it has a narrow therapeutic index (Swartz, 1997), and high potential for nephrotoxicity and ototoxicity (Choudhury and Ahmed 1997).

Sulphamix is a compound contain mixture of sulphadimidine sodium, sulpha- diazine sodium and sulphathyazol sodium and used in treatment in both enterites and pneumonia in calves.

The present study was done to identify the most common bacteriological and protozoal causative agent of diarrhoea and investigate the efficacy of gentamicin and Sulphamix either alone or together.for the treatment of diarrhoea in newlly born frezian-calves. Moreover, the effect of diarrhoea on the haematological picture and some biochemical parameters were evaluated. 


\section{MATERIALS AND METHODS}

\section{1) Animals:-}

This study was carried out in a private farm at Hehia city (ElSharkia-Province) during the period from sept.2005to Feb.2006. A total number of 58 calves suffering from diahrroea aged from 10-30 days old weighting 40-60 kg suffering from diahrroea are examined for isolation and identification of the cauaetive agent .

\section{2) Drugs:-}

A- Gentmycin(garavet)R was obtained as a bottle contain $100 \mathrm{ml}$ and/or each $1 \mathrm{ml}$ contain $50 \mathrm{mg}$ gentamicin sulphate as pharmaceutical preparation from Memphis Company for pharmaceutical and chemicals Company,Egypt.

B- Sulphamix it is a trade name for a compound contain mixture of sulphadimidin sodium,sulphadiazine sodium and sulphathyazol sodium and produced by Pharma Swede Company-Egypt

C- Rehydro-Zinc is a trade name for electrolyte mixture produced as sachet and Manufactured by chemical industries development Co.(CID)A.R.E

\section{3) Experimental design:-}

28 calves were used in this investigation,randomly divided into four equal groups.First group was clinically healthy calves free from internal and external parasite (control), second group was calves suffering from diarrhea due to bacterial causes and treated by Gentamycin at a dose of $1 \mathrm{ml} / 10 \mathrm{~kg}$. b.wt. daily by the intramuscular route from the respective drug for 4 consecutive days and fluid and electrolyte replacement, Rehydro-Zinc,(one sachet/200ml water as drench twice daily),third 
group was calves suffering from diahrroea due to cryptosporidia and treated by sulphamix in a dose of $10 \mathrm{gm} / 50 \mathrm{~kg} \mathrm{~b}$.wt. orally daily for 4 consecutive days and fluid and electrolyte replacement, RehydroZinc, (one sachet $/ 200 \mathrm{ml}$ water as drench twice daily) and fourth group was calves suffering from diahrroea due to mixed infection and treated by sulphamix and Gentamycin by same dose and route of administration and fluid and electrolyte replacement,Rehydro-Zinc,(one sachet/ $200 \mathrm{ml}$ water as drench twice daily).

\section{Bacterial examination:-}

Sterilized swabs were tacken from rectum of apparently healthy and diarrhoeic calves for bacteriological examination. The collected samples were incubated on nutrient broth at $370 \mathrm{C}$ for $24 \mathrm{~h}$.,then subcltured into selective media according to Woldehiwet,et.al. (1990). All bacterial isolates were identified after Holt, et. al. (1994).

\section{Antibiotic sensitivity:}

The in vitro antibiotic sensitivity test of different isolated microorganism against antibacterial agents was carried out using disc method described by Cruickshank, et. a1. (1975). The antibiotics used were gentamycin (10ug) erythromycin (15ug), flumequine, (30ug), neomycine (30ug),enrofloxacine(10ug), nalidic acid (30 ug) and colistin (10ug).

\section{3) Sampling:-}

\section{1) Faecal samples:}

Individual faecal samples were collected from all examined animals using sterile probes introduced into the rectum of each calves and kept in sterile plastic bottles.All samples were labeled and sent to laboratory for parasitological examination through 
a- Direct faecal smear (Soulsby,1986).

b- Concentration flotation technique (Levine,1987).

c- Thin faecal smear are made and left to dry, then fixed with methanol for 10 minutes, and stained with modified Ziehl-Neelsen stain according to Henriksen and Pohlenz (1981). Finally, the smears were screened under the oil immersion lens for detection of cryptosporidial oocysts.

\section{2) Blood samples:}

Two blood samples were collected from control and infested calves before and after treatment by10,20 and 30days post treatment First sample was collected in heparenized tube for haematological study and second sample was collected in centrifuge tube to obtain clear serum for clinico-biochemical study.

\section{A) Haematological studies:-}

Blood picture was performed according to techniques described by Jain (1986).

\section{B) Biochemical studies:-}

Sera of calves were analysed for determination of serum transaminases (AST-ALT) colouremetrically according to (Reitman and Frankel, 1957) alkaline phosphatase (John, 1982), total protein (Doumas, et. al. 1981) albumin (Drupt 1974) globulin was calculated as difference between total protein and albumin, glucose (Siet, et. al., 1981). Serum urea (Patton and Crouch, 1977), creatinine(Henry, 1974) Serum calcium (Gindler,1972), inorganic phosphorus (Golden- bery, 1966). magnesium (Gindler and King, 1971) sodium and potassium (Oser 1979).

\section{4)Statistical analysis:-}

Our data were tabulated and statistically analysed according to Spsswin (1995). 


\section{RESULTS}

\section{A) Bacteriological isolation:-}

The results of bacteriological and parasitological examination of faecal samples and faecal swabs revealed that the main aetiological agents responsible for diarrhea in calves were E.coli,proteus sp., kelbisella sp.and mixed infection (E.coli and Proteus sp.-E.coli and Kelbisella sp.) in precentage of $20.69 \%, 13.79 \%, 10.34 \%, 6.90 \%$ and $12.07 \%$ respectively, Moreover cryptos- poridium sp.was found in (36.20\%) in diarrhoeic calves either alone $(13.79 \%)$ or mixed with bacteria (E.coli and Cryptospordium sp., Proteus sp. and Cryptospordium sp., Klebsiella sp.and Cryptospordium sp. $6.90 \%, 10.34 \%$ and $5.17 \%$ respectively) table (1).

\section{B) Antibacterial sensitivity tests:-}

Antibiogram studies reveald that the activity of gentamycin and other antibiotic disc in vitro against previous isolated bacteria from diarrhoeic calves either in alone or mixed infection by disc diffusion test,showed that the gentamycin was the highest effective than other tested drug followed by enrofloxacin flumoquine,erythromcin and neomyc- ine but all isolated microorganisms not sensitive to Nalidixic acid colistin as in table (2).

\section{C) Haematological values:-}

Haemogram picture of diarrhoic calves due to bacteria or crytosporidia either alone or mixed infection induce significant increase in erythrocytic count haemoglobin content,packed cell volume percent table 
(3) mean while leukogram picture of diarrhoic calves due to bacteria revealed a significant increase in total leukocytic count,eosinophils and significant decrease in monocytes coupled with insignificant increase in neutrophils,lymphocyte basophil but diarrhoic calves due to crytosporidia revealed a significant increase in total leukocytes count and lymphocytes but induce insignificant increase in neutrophils and insignificant decrease monocytes, eosinophil and basophil, table (4).

\section{D) Biochemical studies}

Regarding to the proteinogram variations(table5)It was noticed that the diahrroea in calves due to bacteria or crytosporidia either alone or mixed infection induce significant decrease in total protein, albumin and globulin but albumin/globulin ratio insignificantly decreased. It so clear evident from table (6) that the diahrroea in calves in the calves suffering from diarrhoea due to bacteria or crytosporidia either alone or mixed infection induce significant elevation in the transaminases enzymes (AST-ALT)and alkaline phosphatase.The results demonstrated in table (7) revealed significant increase in the mean values of blood serum urea, creatinine and potassium while significant decrease in The results demonstrated glucose, calcuim, inorganic phosphorus, magneisum and sodium were observed in diarrhoic calve due to bacter- ial ,crytosporidia and mixed infection but chang of biochemical parameter due to mixed infection is more sever. 
Table (1): Incidence and causes of diarrhoea in newly born calves.

\begin{tabular}{|c|c|c|c|}
\hline $\begin{array}{c}\text { Etiological } \\
\text { factor }\end{array}$ & Type of microorganisms & $\begin{array}{l}\text { Number of } \\
\text { Calves (58) }\end{array}$ & Percent \\
\hline \multirow[t]{3}{*}{ Bacterial agents } & E.coli & 12 & 20.69 \\
\hline & Proteus sp & 8 & 13.79 \\
\hline & Klebsiella sp . & 6 & 10.34 \\
\hline \multirow[t]{2}{*}{ Mixed bacterial agents } & Proteus sp.and E.coli & 4 & 6.90 \\
\hline & Klebsiella sp.and E.coli & 7 & 12.07 \\
\hline Parasite & Cryptosporidium sp. & 8 & 13.79 \\
\hline Mixed infection & Cryptospordium sp.\& E.coli & 4 & 6.90 \\
\hline \multirow[t]{2}{*}{ Bacterial and parasite } & Cryptospordium sp.\& Proteus sp. & 6 & 10.34 \\
\hline & Cryptospordium sp.\& Klebsiella sp. & 3 & 5.17 \\
\hline
\end{tabular}

Table(2): Sensitivity tests of isolated organisms against different antimicrobial agent.

\begin{tabular}{|c|c|c|c|c|c|c|}
\hline $\begin{array}{l}\text { Antibiotic } \\
\text { disc }\end{array}$ & $\begin{array}{l}\text { Conc. } \\
\text { of disc }\end{array}$ & E.coli & $\begin{array}{c}\text { Proteus } \\
\text { sp. }\end{array}$ & $\begin{array}{c}\text { Klebsiella } \\
\text { sp. }\end{array}$ & $\begin{array}{c}\text { Proteus sp. } \\
\text { coli \& E. }\end{array}$ & $\begin{array}{c}\text { Klebsiella } \\
\text { sp. aE. } \\
\text { coli }\end{array}$ \\
\hline Gentamycin & 10ug & +++ & ++ & + & ++ & ++ \\
\hline Erythromycin & $15 \mathrm{ug}$ & +++ & ++ & + & ++ & ++ \\
\hline Flumequin & $30 u g$ & ++ & + & + & ++ & ++ \\
\hline Neomycin & $30 u g$ & + & ++ & - & + & + \\
\hline Enrofloxacin & 10ug & +++ & + & + & + & ++ \\
\hline Nalidic acid & 30ug & + & - & - & + & + \\
\hline Colistin & 10ug & - & - & - & - & - \\
\hline
\end{tabular}

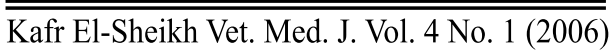




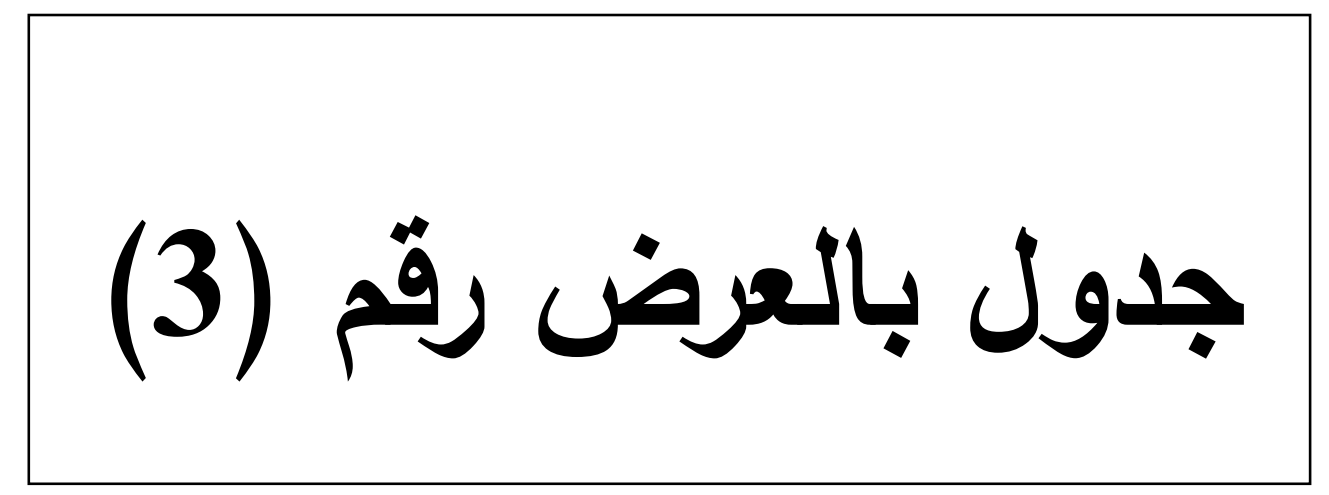




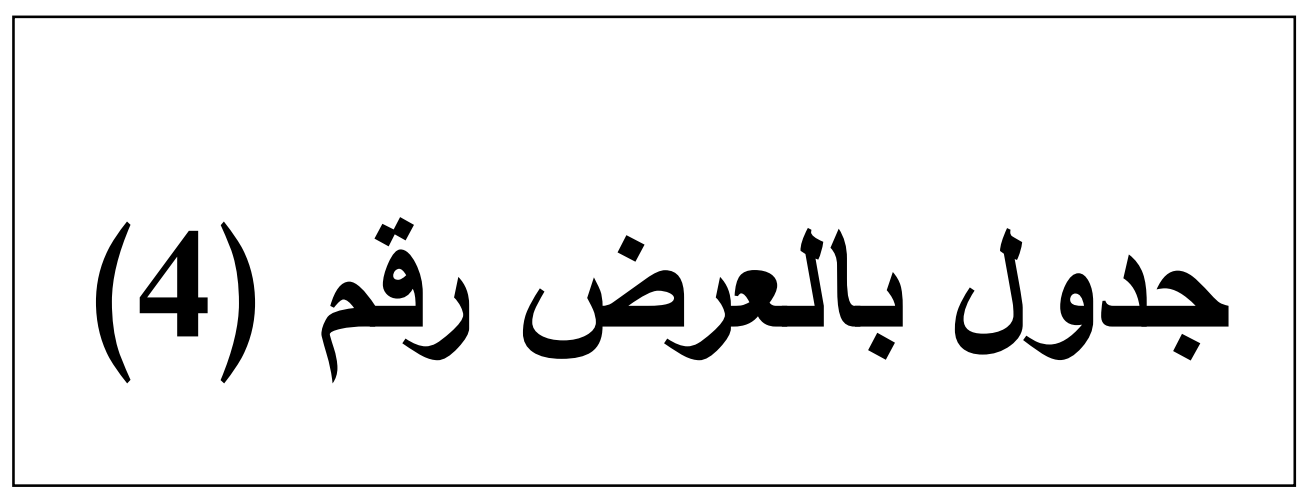

$\overline{\overline{\text { Kafr El-Sheikh Vet. Med. J. Vol. } 4 \text { No. } 1 \text { (2006) }}}$ 


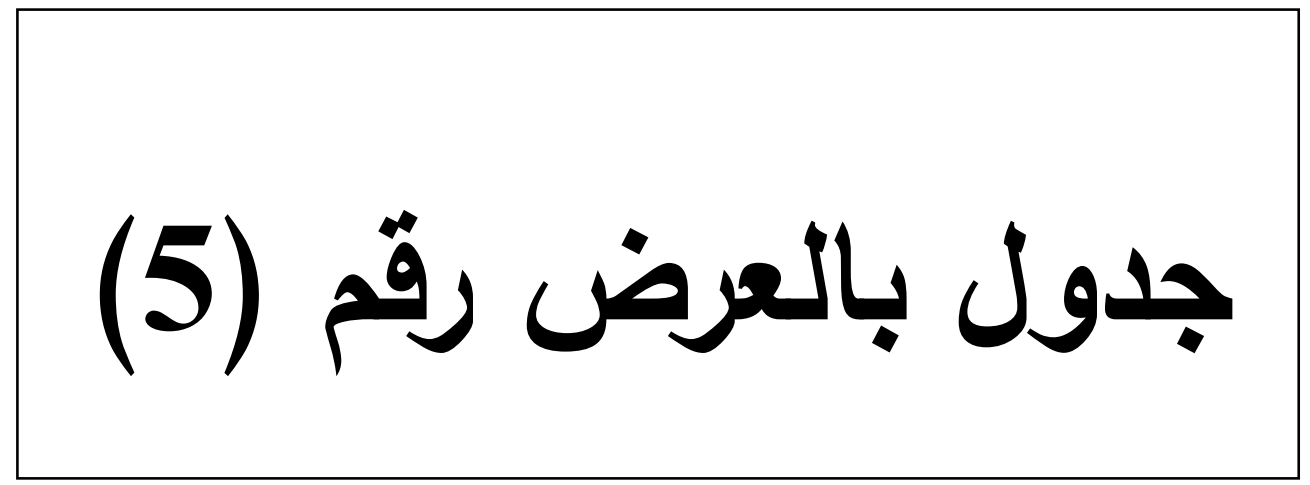




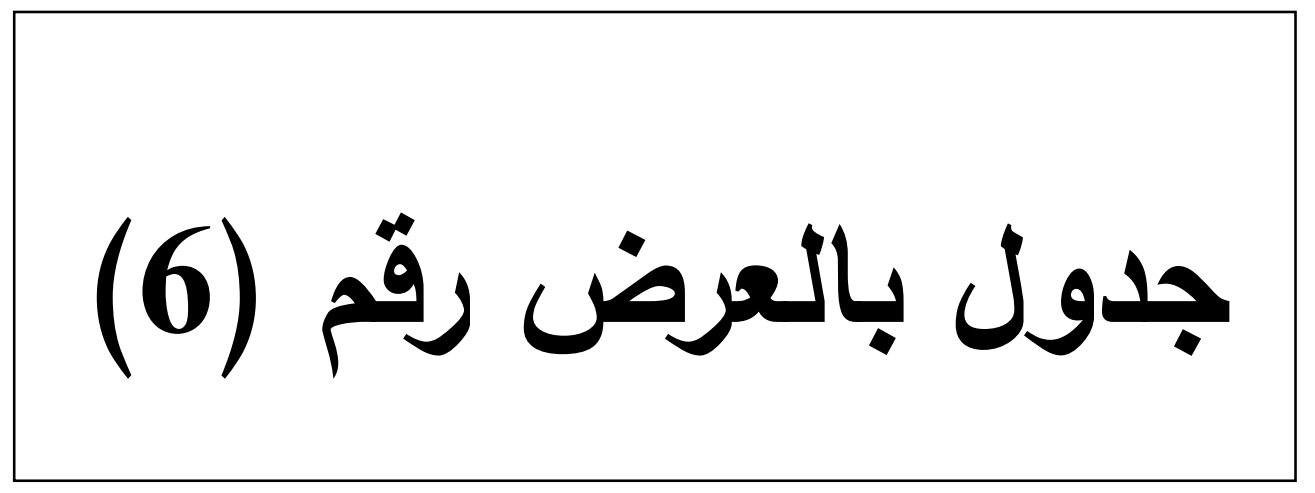




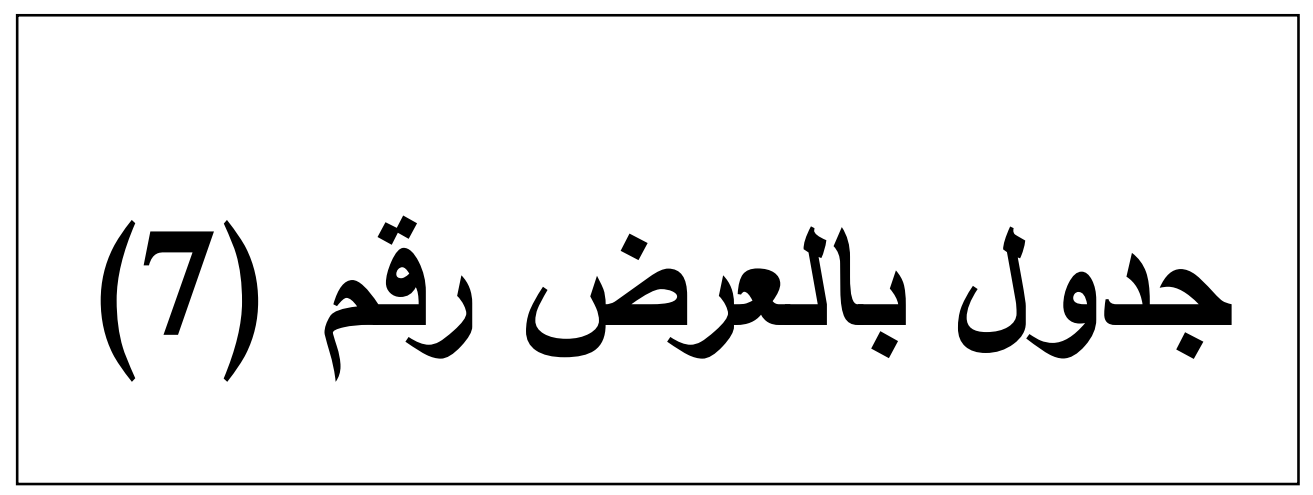




\section{DISCUSSION}

The newly born animals were reliable to suffer severely from a variety of enteric disease due to viral, bacterial, parasitic, nutritional and hygienic condition because they are transferred suddenly from sterile intrauterine life condition to an extra uterine with surrounding environments rich in various pollutants which decrease their general body resistance making them susceptible to severe disease conditions (Jubb, et. al. 1985).

The obtained results in our study revealed that The main aetiological bacterial agents responsible for diarrhea in calves in examined faecal swabs collected from 58 fresian-calves were E.coli,proteus sp.,kelbisella sp.either alone or in mixed infection as(E.Coli and proteus sp.-E.Coli and kelbisella sp.) in precentage of $20.69 \%, 13.79 \%, 10.34 \%, 6.90 \%$ and $12.07 \%$ respectively. From our results,E.coli is the highest percentages from the isolated enteric bacterial species that cause diarrhoea in newlly born calves. Similar findings were recorded by Reynolds, et. Al .(1986) They mentioned that,E.coli was predominant enteropathogens causing enteritis and diarrhoea in neonatal calves. The disease is usually referred to be as colibacillosis and include either enteric or systemic colibacillosis (Farid, et. al. 1992) Found that the main bacterial cause of diarrhea in newlly bore calvesa is E.coli and kelbisella .Our results were also similar to that reported by Harbby (2002). Who mentioned that other species of family enterobacteriaceae as proteus sp. and kelbisella sp. are also detected in fecal swabes from diarrhoeic calves. El-Gaml, et. al. (2001) who reported that, Cryptosporidium is most frequently seen in animals between few days and one month of age. Moreover Fayer, et. al.(1997) reported that,young animals are severely affected by Cryptosporidium,as far as they are immunologically immature and consequently have agreater susceptibility to the infection by this parasite. 
Disc diffusion test is widely used for antimicrobial sensitivity test for reasons of time, simplicity and cost (Green Wood 1978). In present study by using the disc-diffusion test showed that the gentamycin was the highest effective on all isolated organisms than other tested drug followed by enrofloxacin,flumoquin and erythromcin but all isolated microorganisms not sensitive to Nalidixic acid and colistin. These results are in agreement with those obtained by El-Sayed, et. al.(1998) who recorded that gentamycin had high inhibitory effect on E.coli and Klebseilla in diarrhoeic camels.Also our results coincide with those obtained by (Sayed, et. al.2001) who mentioned that E.coli isolate from diarrhoeic lambs were sensitive to gentamycin with 92\%.El-Gaml, et. al.(2001). Found that the most effective drugs for treating of E.coli isolated from diarrhoeic kid were gentamycine and enrofloxacin Orden, et. al. (2000) Concluded that E.coli strains isolated form diarrhoeic lambs sensitivite to gentamycin with $95 \%$ and resistant to nalidixic acid. In addition Aisha (2001) Recoded that all tested serogroups of E.coli isolated from diarrhoeic calves were found to be sensitive to gentamycin and enrofloxacine and resistant to nalidixic acid.

The present investigation revealed that a significant increase in the total erythrocytic count,haemoglobin content and packed cell volume percent in diarrhoic calves due to bacterial or crytosporidia sp. either alone or mixed infection but mixed infection more affected.These results are comparable with the results obtained previously byKamel and ElKabany (2005) They menti- oned that a significant increase in total erythrocytic count in diarrhoeiccalves due to bacterial causes.AlsoSadiek and Sohair (1999) mentioned that diarrhoea in calves due to bacterial agent cause significant increase in the total erythrocytic count,haemoglobin content and packed cell volume percent.This chang may be 
attributed to the occurrence of dehydration and hemoconcentrat- ion arised from diarrhoeaMolina, et. al.(1994) and Omran et.al. (2005a) in diarrheic calves.Dehydration and haemoconcentration could be attributed to the loss of body fluids especially blood plasma in hypersec-retory diarrhoea Tawfik, et. al.(2004).Also Ahmad (2002) mentioned that significant elevation in erythrocytic count and packed cell volume was common feature in crytosporidia sp diarrhoic calves. This obeservation may be attributed to the pathogenecity of the crytosporidia which adhere to microvillous border of enterocytes of both small and large intestine causing sever diarrhoea and hemoconcentration (Pohlenz et. al.1978).

In the present experiment,diarrhoic calves due to bacteria revealed a significant increase in total leukocytic count,eosinophils and significant decrease in monocytes coupled with insignificant increase in neutrophils, lymphocyte basophil.Close similarity was seen between the present finding and these obtained by Amer, et .al.(1983) in newly born Holstein frestein calves suffering from diarrhoea due to bacterial causess. The increase in total leukocytes count may reflect the condition of bacterial enteritis which may by primary or secondary to parasitic infestation Molina ,et. al. (1994). Also Doxey (1983) mentioned that the increase in total leukocytic count may due to iflammatory response in the gastrointestinal tract due to bacterial infection.Diarrhoic calves due to crytosporidia revealed chang in leukogram repersenn- ted by a significant increase in total leukocytes count and lymphocytes but induce insignificant increase in neutrophils and insignificant decrease monocytes, eosinophils and basophil. These changes were in coincidence with the results of Ahmad (2002). These variation could be attributed to the destructive effective of cryptosporidia oocysts on the epithelial cells of the gastrointestinal tract walls Omran et. al. (2005b). 
Concentrations of total proteins, albumin and globulin in the calves suffering from diarrhoea due to bacteria or crytosporidia either alone or mixed infection in our gained results (table5) were evident to show significant decrease but $\mathrm{A} / \mathrm{G}$ ratio insignificantly decreased in comparison with apparently healthy calves. These results are comparable with the results obtained previously by Fitzgerald and Mansfield (1972) in newly born Holstein friestein calves suffering from diarrhoea due to bacterial causess. The present observation in diarrhoic caslves due to bacterial cause may be attributed to the general unthriftines which may affect worsely the hepatic parenchyma resulting in the failure of the liver for protein synthesis Tawfik, et. al.(2004). Also the above mentioned results were supported by previous studies Ahmad(2002) in calves suffering from diarrhoea due to crytosporidia. This results could be attributed to the inability of the gut in parasitized animals to absorb and assimilate the haemopoietic principals Regarding blood serum total protein,albumin and globulin and a state of anorexia and inability of the synthesis proteins Radostits, et. al.(2002)and Omran, et. al. (2005b).

Our study revealed a significant increase in the activities of the liver enzymes (AST-ALT) and alkaline phosphatase in diarrhoic frezian calves due to bacterial ,crytosporidia and mixed infection.Similar results were reported in diarrhoic calves due to bacterial causes (Wittum, et. al. 2002). The present observation may be attributed to degenerative changes and necrotic processes accompanied the formation of intestinal and hepatic lesions due to bacterial infections and its toxins (Omran, et. al. 2005a). Elevation in activity of transaminases (AST, ALT) and alkaline phosphatase in diarrhoic calves du to cryptospordium in comparison to healthy ones were coincided with Omran ,et. al. (2005b). Changes in liver enzyme activity due to crytosporidium could be attributed to the epithelial tissues damage of the intestinal walls by the parasites and its toxins Russel (2003). 
In the present study it has been observed that diarrhoea in calves cause deleterious effects on biochemical constituents of serum elicited a significant increase in the mean values of blood serum urea and creatinine and significant decrease in glucose were observed in diarrhoic calve due to bacterial, crytosporidia and mixed infection but change of biochemical parameter due to mixed infection is more severe.Similar results were previously reported by Radostits, et. al. (2002). They found that significant increase in urea and creatinine but glucose significantly decreased in sera of diarrhoic sheep and calves respectively due to bacteria and crytosporidia infections. Such findings may be attributed to excessive production of urea and creatinine by increased protein catabolism processes in severe toxic and febrile conditions, reduced renal function and the beginning of nephropathological changes Radostits, et. al. (2002). Decreased glucose level may be paralle to result recorded by Hassan et. al. (1985) They attributed hypoglycemia in buffalo calves suffering from E.coli enteritis to anorexia, decreased intestinal glucose absorption, a low level of glucose reserves in young age and alterations in tissue metabolism caused by decreased blood flow and oxygenation associated with the hypovolemic shock present in the hypoglycemic diarrhoeic animals the. Coles (1986) added that the hypoglycemia in case of enteritis resulted from lack in intestinal absorption.

Statistical analysis of the obtained result revealed a significant decrease in serum calcium inorganic phosphorous,magnesium and sodium while a significant increase in the mean values of potassium were observed in diarrhoic calve due to bacterial, crytosporidia and mixed infection but change due to mixed infection is more sever as compared to healthy one.Our results were reinforced with that of. Assad and Nizar (2004) They found that serum calcium, inorganic phosphorus and magnesium were significantly decreased while potassium was signifi-cantally increased in sera of diarrhoic sheep and calves respectively due to bacteria and crytosporidia infections. These results were in agreement with the finding obtained by Ramadan, et. al. (1985) who recorded significant hyponateremia,hypomagnes- emia and hyperkalemia in diarrhoeic calves. Coles (1986) attributed the decrease in serum calcium level to hypoalbuminemia, where decreased albumin concentration lowers the 
total calcium level,while,both ionized and complex calcium levels remain normal. Also Fisher and Dela (1972) reported that sodium is the most abundant ion in the extracellular fluid and exposed to loss in diarrhoea stools as they are components of the gastrointestinal secretions. Hypophosphatemia and hypomagnesemia mainly due to decrease in feed intake and mal absorption (Blood and Radostitis, 1989). Increase in serum potassium in diarrhoic calves found in the present study may be due to potassium leave the intracellular space to the extracellular one instead of hydrogen ion to compansate acidosis ocurred during diahrroea (Blood and Radostitis, 1989).

From the previously mentioned point we could concluded that the diarrhoea in calves due to bacterial, crytosporidial and mixed infection induce some adverse effect on biochemical parameters which returned to the normal levels 30 days post treatment by gentamycin and sulphamix either alone or together.

\section{ACKNOWLEDGEMENT}

Thanks to Dr. Khalid El-Kholany senior researcher,Animal Health Research Institute, Zagazig Lab(parasitology Department). For his help in this work.

\section{REFERENCES}

- Abd Ellha,Mona,A. (2004): Bacteriological, serological and biological studies on E.coli strains isolated from diarroeic kids and lambs in north sinai. Alex. Vet.Med. J.21(1)221.

- Ahmad, Nagwa, S. (2002): Serum protein profile in cattle calves infested with cryptosporidia species.Egypt J. Comp. and Clinical Path. 15 (1)149-155.

- Aisha, R (2001): Comparative Studies on Diarrhoea Caused by E.coli in Farm Animal Egypt Vet. Med. Ass. 61,6c,2001.

- Anderson, B.C.and Hall.R.(1982): Cryptosporidial infection in Idaho dairy calves. J. Am. Vet. Med. Assoc. 181: 4 84-485. 
- Amer, A.; Hassan, N.; El-Sebaie, y.; Bayoumi, A. and Ibrahim, A. (1983): Studies on an out- break of colibacillosis among newlyborn Holstein friestein calves in the Newvally, Egypt.1-Clinical heamatolo-gical, Aetiological and pathological alteration .AssiutVet. Med. J.14, 27:151-157.

- Assad, A.and Nizar, A.(2004): Studies on the clinical,haematological and biochemical changes in the diarrhoeic calves.Alex. Vet. Med. J. 21 (2)712-719.

- Bazeley, K. (2003): Investigation of diarrhoea in neonatal calves. Ind. Practice.25:152.

- Bellinzoni, R.C. (1990): Some studies on enteritis in young calves. Res.Argentina de Microbiología, 22: 130-137.

- Blood, D. C. and Radostitis, O. M (1989): Veterinary Medicine.A text book of the diseases of cattle, sheep, pigs, goats and horses.7th Ed. Bailliere London Philadelphia ,Sydney , Tokyo, Toronto.

- Bryan,L.and Kwan,S. (1983): Roles of ribosomal binding, membrane potential and electron transport in bacterial uptake of streptomycin and gentiamicin.Antimicrob. Agents Chemother, $23: 835$ - 845 .

- Choudhury, D. and Ahmed, Z. (1997): Drug induced nephrotoxicity. Med. Clin. North Am.

- Coles, E.(1986): Veterinary Clinical Pathology. $4^{\text {th }}$ Ed. W.B. Saunders Comp. Philadelphia ,London and Toront.

- Cruickshank.;Duguid,J.;Marmion, B. and Swain R.(1975): Medical Microbiolgy 12t" Ed. W. and S.living limited Edingurg and London. 
- Cullor,A.(1985): Diarrhoea in neonatal calves.Proceedings Conf. Res. Animal Dis.35.

- Doumas, B.; Carter, R.; Peers, T. and Schaffer, R. (1981): Method for determiina- tion of total protein in serum.Clin.Chem.27.1642.

- Drupt, F. (1974): Colorimetric methed for determination of albumin. Phar. Bio.(9).

- Doxey, D.(1983):Clinical pathology and diagnostic procedure $2^{\text {nd }}$ Ed. Bailliere tindal London.

- El-Gaml, A.; Hashem- ME; Hatab, M (2001): Diarrhoea in kids attributed to E.coli andcryptosporidium.AssiutVet.Med.J.45:89,132-143;35 ref.

- ElSayed, A.; Sadiek, A.; Aly, A. andIsmail, M. (1998): Clinical and laboratory invetigations on diarrhoea in camels in association with stress factors in Assiut Governorate.AssiutVet.Med.J.40(79)83-95.

- Farid, A.; Kaldas, T. andSadd, K. (1992): prevalence of Escherichia Coli k99 in diarrhoeic newborn calves. Proc. $5^{\text {th }}$ Sci. cong., Fac vet. Med. Assuit.

- Fayer, R.; Speer, C. and Dubey; J. (1997): The general biology of Cryptos- poridium, p.2-41.In:R.Fayer (ed.),Cryptosporidium and Cryptosporidiosis. CR.C Press, Boca.

- Fisher, E. and Dela, G. (1972): Water and electrolyte studies in new born calves with particular reference to the effects of diarrhoea. Res. Vet. Sci. 13: 31. 
- Fitzerald, P. and Mansfield, M. (1972): The effect of bovine coccidi-osis on certain blood components, feed consumption and body weight changes of calves Am. J. Vet. Res., 33:1391.

- Gind1er,E.(1972): Determination of serum calcium level.Am. J.Clin, Path. (58) 37.

- Gind1er, E. and King, D. (1971): Determination of serum magnesium clin Chem.17.

- Goldenbery,H.(1966): Determination of serum inorganic phosphorus. clin. Chem.12.

- Green wood, D. (1978): Activity of flumquine against E.Coli in vitro comparson with nalidixic acid and oxalnic acid. ant. Microb. agent and cremoth.(13)479-483.

- Harbby, H.A. (2002): Bacterial causes of diarhoea in small animals (kids, Lambs and calves) in Sultanate of Oman. J. Egypt. Vet. Med. Ass. 62 (3): 227-235.

- Hassan, Kn.K.; El-Sebaie, A. and Amer, A.A. (1985): Studies on an outbreak of colibacillosis among newly Holstein Friesian calves in the New Valley, Egypt.II- Some serum biochemical and electrolytes changes. Assiut Vet.Med.J.Vol.14(27)16.

- Henriksen,S.A. and Pohlenz, J. F. (1981): Staining of cryptosporidia by a modified Zieh-Nelsoen technique. Acta Vet Scand,22(3-4):

594-596.

- Henry, R. (1974): Colorimetric determination of creatinine. Clin. Chem. Prinicipales. 
- Holt, J.; Krieg, N.; Smeadb, P. J. and Williams, S. (1994): Bergey's Manual of Determinative Bacteriology. $9^{\text {th }}$ Ed. Williams and Wilkins Co.; Baltimore.

- Jain, N. (1986): Schalm's Veterinary Haematology $4^{\text {th }}$ Ed., Lea and Fibiger, Philadelphia, U.S.A.

- Janoff, E.N and Reller L.(1987): Cryptosporidium species, a Protean Protozoan. J. Clin. Microbiol. 25: 967-975.

- John, D. (1982): Clinical laboratory mothed for determination of alkaline phosphatas $9^{\text {th }} \mathrm{Ed} .580-581$.

- Jubb, K.; Kennedy, P. and Paler, W (1985): Pathology of domestic animals (1),Academic Press in Cortondo, Florida, U.S.A.

- Kamel, A.and El-Kabany, M. (2005): Disturbances in acidbase bal-ance and electro- lytes associated with diarrhoea in buffalo calves and their treatment. $4^{\text {th }}$ Conf. of Faculty of Vet. Med.Mansoura University 5903-913.

- Karlowsky, J.; zelenits, S. and Zhanel G.(1995): Efficacy of aminogl-ycoside in treating drug resistant gram-negative bacteria. Aminoglyc-oside adaptive resistan resistance pharmacotherapy (17) 549-55.

- Kirkpatrick, C. E.(1985):Cryptosporidium infection as a cause of calf diarrhea. Vet. Clin. North Am. Food Anim. Pract. 1:515:528. 
- Levine, M. (1987): E.coli the cause diarrhea, enterotoxigenic, enterop-athogenic, enteroinvasive, enterohemarhagic and enteroadherent. J. inf. Dis., 155:377-38.

- Molina, J.; Radriguez, P. E.; Ferres, O.; Cutierr, A.andHernandez, (1994): Biopthological data of goat kids with cryptosporidiosis.Vet. Rec.135. (67):67-68.

- Omran, H.; Anwaar, M. and Selim, A. (2005a): Clinicohaematological and bioch- emical studies on buffalocalves suffering from diarrhoea and alopecia with trials for treatment.Zag.Vet.J.33(1)255-231.

- Omran, H.; Anwaar, M. A. and Nagwa, A. (2005b): Clinicohaematological and serum biochemical studies on buffalocalves suffering from cryptosporidiosis with trials of treatment.4th Conf. of Faculty of Vet. Med. Mansoura University 565-574.

- Orden, J.; Ruiz, S.; Garcia, S. and Fuente, $R$. (2000):Quinolone resi-stance in E.coli strains from diarrhoeic lambs in Spain. Vet.Record. 2000, 147:20, 576-578; 26 ref.

- Oser, B. L. (1979): Hawk's physiological chemistry. $14^{\text {th }}$ ed. MCGraw Hill company, Ltd., London.

- Patton, C. and Crouch, S.(1977): Colorimetric determinat of urea in blood. Anal. Ch. Chem.49:464-469.

- Pohlenz, J.; Mann, H.; Cheville, N. and Bemrick, W. (1978):

Cryp-tosporidiosis as a probable factor in neonatal diarrhoea of calves. J. Am.Vet. Med. Ass. 172: 452 -457 
- Pugh, D. (2002): Sheep and goat medicine.W.B.Saunders Company U.S.A. first Ed.

- Radostitis, O.; Blood, D.and Gay, C. (2002): Veterinary Medicine, $10^{\text {th }}$ edition, P.P.1343,Bailliere Tindall, London, Tokyo, Philadelphia.

- Ramadan,S.,Hussein,M.;Itman,R.,El-Neweehy,T.; Abu-Zeid, A.and Arab,R.(1985): Studies on some enzymatic and acid- base disturbances in Egyption buffaloe calves suffering from enterities .J. Egypt .vet .Med .Ass. ,45:175.

- Reitman, S. and Frankel ,S. (1957): Colorimetric determination of S. AST, S.ALTenzymatic activity.An.J.Clin.Path,28:56.

- Reynolds,D.J.,Morgan,J.H. and Jones, P.W(1986): Microbiology of calf diarrhoeain Southern Britian. Vet. Rec., 119: $34-39$.

- Russel,S.(2003): The effect of cryptosporidiosis on certain biochemica constituentsof calves.Vet.Parasit.II.255-260.

- Sadiek and Sohair Z.Hussein (1999): Acute enteritis in neonatal friesian claves in sohag governoate with special reference to etiology. Assuit Vet.Med.J.42(8)163:174.

- Sayed, A.; Abd El- Hafeez, M.; Thabet, A. and Bastwros F. (2001): Studies on diarrhea in lambs in Assiut Governorate. Assiut Vet.Med. J.46 (91)109-122. 
- Siet,G.;Henny, J. and Schiele, F. (1981): Interpretation des examens de laboratior .KargaEd.PP.206.

- Smith, M. A. and Sherman, D.(1994):Goat medicin. Philadephia, Le \& Febiger.

- Soulsby E.J.L. (1986): Parasitology of Demosticated Animals. $7^{\text {th }}$ Ed., Bailliere, Tindell, London.

- Spsswin, K. (1995): Software packet for Statistical analysis(under window US A.

- Swartz,M.(1997): Use of antimicrobial agents and drug resistace. Engl J Med (337) 91-94.

- Tawfik, S.A. El-Ramady, R.A. and Rawia, KH. E. (2004): Some hematological and biochemical changes associated with deviated appetite in growing cattle. $7^{\text {th }}$ Vet. Med. Zag. Conference.(21-23 July, 2004) Sharm El-Sheikh.

- Tobin, T. (1979): Pharmacology review: Streptomycin, gentamicin, and theaminoglycoside antibiotics J.Equine Med Surg3:206-212.

- Wittum, T.; Salman, M.; Odde, K. and King, M. (2002):Causes and costs of calve mortal-in Colorado beef herds. JAVMA (203)2., July. 15: 232 - 236.

- Woldehiwet, Z.; Mamache. B. and Rowan, T. G. (1990): The effects of age,envirome ntal temperture and relative humidity on the bacterial flora of the upper respiratory tract in calves. $\mathrm{Br}$. Vet.

$\mathrm{J}$.

211-218. 
محاولة حقلية لعلاج الإسهال في العجول البقرى بمحافظة الثرقية

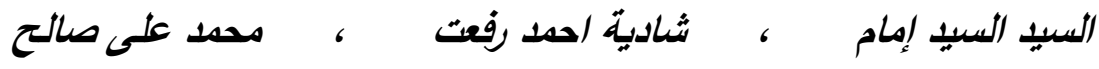

\section{معهز بحوث صحة الحيوان(الزقازيق)}

استهدفت هذة الدراسـة معرفـة مسببات الاسـهال و تاثيرهـا على صسورة الدم وبعض الوظـائف البيوكيميائية فى العجول الفريزيان حديثة الولادة. تم عمل مسـح لعدد 58 عجل بقرى فريزيان تعانى مصابون بالإسهال تتراوح أعمارها من(10- 30 يوم) فى احدى المزارع الخاصة بمدينة ههيا بمحافظة الثرقية وذلك لمعرفة أسباب الإسهال فى العجول حديثة الولادة.

وبالفحص البكتريولوجى تم تحديد المسببات البكتيرية للإسهال فى العجول حديثة الولادة وكانت الأسباب البكتيرية كالآتي:ميكروب القولون العصوي،ميكروب بروتيس ،ميكروب كلبسيلا وعدوى مشتركة (الميكروب العصوي مع ميكروب بر وتيس - الميكروب العصوي مع ميكروب كلبسيلا) بنسب20.69 \% ، 13.79\% ، 10.34\% ، \% \% على التوالي. وبعمل أختبار الحساسية لهذه المعزولات وجد أن

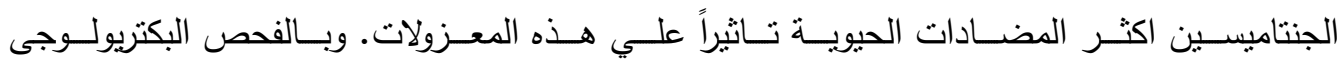
والباراسيتولوجى معا اسفر عن وجود طفيل الكرينوسبوريدا سواء منفرد بنسبة 13.79\%او عدوى مشتركة مع البكتريا (طفيل الكريتوسبوريدا مع ميكروب القولون العصوي- طفيل الكريتوسبوريد مع ميكروب بر وتيس طفيل الكريتوسبوريدا مع ميكروب كلبسيلا) بنسب، 6.90\% 10.34\% \% 5 \% على التوالي. فـى هذه الدراسـة تقسيم عدد 28 عجل مـن العجول التـى تم عمل مسـح عليهـا الى اربـع مجموعات تحتوى كلا منها على 7 عجول المجموعة الأولى عجول سليمة وبصحة جيدة خالية من الطفيليات الداخلية والخارجية( ضابطة) المجموعة الثانية تعانى من وجود إسهال نتيجة لأسباب بكتيرية وتم علاجها باستخدام الجنتاميسين بالجرعة العلاجيـة بالإضـافة الى محلول ريهيدرو زنك المجموعة الثالثذة تعـانى من وجوداسـهال نتيجة لوجود طفيـل الكريتوسبوريدا وتم علاجها باستخدام السلفامكس بالإضافة الى محلول ريهيدرو زنك،،المجموعة الرابعة تعانى من وجود إسهال نتيجة لعدوى مشتركة من Kafr El-Sheikh Vet. Med. J. Vol. 4 No. 1 (2006) 
البكتريا وطفيل الكريتوسبوريدا وتم علاجها باستخدام الجنتاميسين والسلفامكس معا بالإضافة الى محلول ريهيدرو زنك. بعد نهاية العلاج ب 20,10 ، 30 يوم تم أخذ عينتين دم من كل حيوان الأولى على

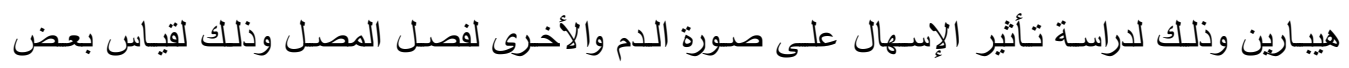

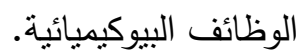

تثــير النتـائج أن الاسـهال فـى العجـول حديثـة الـولادة نتيجــة للإصـابة بالبكتيريـا او طفيـل الكريتوسبوريدا أدى الى حدوث زيادة معنوية فى عدد كرات الدم الحمراء، تركيز الهيموجلوبين، حجم خلايا الدم المرصوصة ولكن الإسهال نتيجة للإصابة بالبكتريا أدى الى زيادة معنوية فى عدد كرات الدم البيضاء ، الخلايا الحامضيه ونقص معنوى فى الخلايا الملتهمة الكبيرة مع حدوث زيادة غبر معنوية فى لـ الخلايـا المتعادلـة، الخلايـا الليمفاويسه و الخلايـا القاعديـة ولكـن الإنــهال نتيجـة للإصـابة بطفيـل الكريتوسـبوريدا أدى الـى حـدوث زيـادة معنويـة فـى عـدد كـرات البيضــاء والخلايــا الليمفاويـة وزيـادة غير معنويـة فى الخلايا المتعادلة و نقص غير معنوى فى الخلايـا الملتهـة الكبيرة، الخلايا الحامضية والخلايا القاعدية.وهذا التغيرات استمرت لمدة عثرين يوما بعد نهاية العلاج. وبدراسـة التغيـرات البيوكيمبائيـة التـى حدثت نتيجـة الإصـابة بالإنسهال النـاتج عن الإصـابة بالبكتريا او طفيل الكريتوسبوريدا او العدوى المشتركة بينهما وجدت زيادة معنوية فى أنزيمي الترانس أمينيزسس(AST- ALT) الفوسفاتير القاعدى ، اليوريا،الكرياتينين والبوتاسيوم ونقص معنوي فى

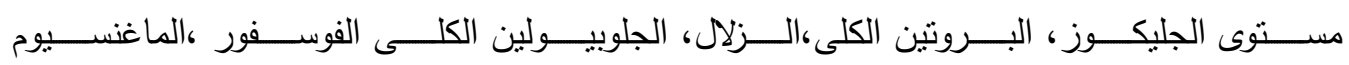
والصوديوم ونقص غير معنوي فى النسبة بين الزلال والجلوبيولين كما وجدنا أن استخدام الجنتاميسين والسلفامكس أديا إلي عودة هذه الوظائف إلي المستوى الطبيعي في مصل العجول المصابة بعد عشرين يوما بعد نهاية العلاج. 